\title{
The Costly War Against Cancer Treatment: The Example of Metastatic Renal Cell Carcinoma in Portugal
}

\author{
A Guerra Dispendiosa do Tratamento do Cancro: 0 \\ Exemplo do Carcinoma de Células Renais em Portugal
}

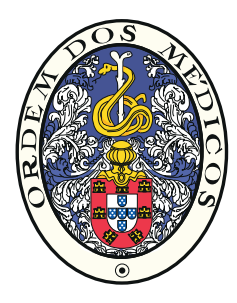

\author{
Pedro Coelho BARATA ${ }^{1}$, Diogo ALPUIM COSTA², José Luís PASSOS COELHO ${ }^{3}$, Ricardo Da LUZ4 \\ Acta Med Port 2018 Jul-Aug;31(7-8):373-375 - https://doi.org/10.20344/amp.9969

\begin{abstract}
Keywords: Antineoplastic Agents/economics; Carcinoma, Renal Cell/therapy; Drug Costs; Neoplasm Metastasis; Portugal
Palavras-chave: Antineoplásicos/economia; Carcinoma de Células Renais/tratamento; Custos de Medicamentos; Metástase Neoplásica; Portugal
\end{abstract}

Kidney cancer is the $12^{\text {th }}$ most common cancer in both men and women, with more than 650 patients (agestandardized rate of 10 per 100000 ) newly diagnosed with renal cell carcinoma (RCC) in 2012, in Portugal. ${ }^{1}$ The 5-year relative survival rate has improved over time but prognosis is still poor, especially for patients with advanced stage disease. ${ }^{2}$

The systemic treatment of metastatic renal cell carcinoma (mRCC) has dramatically changed in the last decade ${ }^{3}$ from a nonspecific immune treatment with interferon and interleukin-2 to the approval of multiple targeted agents against vascular endothelial growth factor/ vascular endothelial growth factor receptor (VEGF/VEGFR) or mammalian target of rapamycin (mTOR). In 2015, the approval of nivolumab and cabozantinib changed the treatment landscape for refractory disease. More recently, tivozanib was approved (in Europe) in the front-line setting. Moreover, in the subgroup of patients with intermediate and poor risk clear cell carcinoma, the combination of two immune checkpoint inhibitors (ipilimumab plus nivolumab) showed further overall survival (OS) advantage over sunitinib for patients with intermediate and poor-risk groups, more strikingly if tumor PD-L1 expression was above 1\%, which, if confirmed, may soon lead to regulatory approval of this combination. ${ }^{4}$

Despite these advances, most patients unfortunately experience disease progression on these therapies. Based on retrospective data from 2005 to 2015 (prior to the checkpoint inhibition era), nearly half (53\%) of mRCC patients received a second-line therapy while less than one fourth $(21 \%)$ received a third line regimen, which is explained in part by the expected clinical deterioration that occurs during the course of the disease. ${ }^{5}$

Health-care costs represent more than $8 \%$ of Portugal's gross domestic product (GDP). ${ }^{6}$ Oncology is responsible for up to $30 \%$ of the total hospital-related costs and the amount spent on anti-cancer therapies is rising fast. ${ }^{7}$ It was the investigators 'perception that the total cost of treatments for mRCC has changed in the last few years but the extent of this change was undetermined.

To assess the 'financial toxicity' associated with the changing landscape in the treatment of mRCC, we carried out a cost-analysis of the systemic treatment for mRCC. The primary objective was to estimate the magnitude of change in the total cost of systemic treatments for mRCC between 2011 and 2018.

The example of a patient with intermediate-risk mRCC (60-year-old, $70 \mathrm{~kg}$, BMl $25 \mathrm{mg} / \mathrm{m}^{2}$ ) treated with a sequence of three different lines of treatment approved by the European Medicines Agency (EMA) ${ }^{8}$ in three different years: 2011 (Case A), 2014 (Case B) and 2018 (Case C) was used here (Table 1). In Case A, the patient sequentially received sunitinib (50 mg daily, 4 weeks on/2 weeks off schedule), everolimus (10 mg daily) and sorafenib (400 mg daily). In case $B$, the sequence of sunitinib (50 mg daily, 4 weeks on/2 weeks off schedule) followed by axitinib (5 mg twice daily) and everolimus (10 mg daily) was considered. In case $\mathrm{C}$, the patient would be treated with the combination of ipilimumab $(1 \mathrm{mg} / \mathrm{kg}$ every 3 weeks for 4 administrations) and nivolumab ( $3 \mathrm{mg} / \mathrm{kg}$ every 2 weeks until disease progression), followed by cabozantinib (60 mg daily) and axitinib (5 mg twice daily). The median progressive-free survival (PFS) reported for each therapy in the leading publications was used for the calculation of duration of treatment. The data from Portugal's medicines agency INFARMED were used to calculate the total cost of anti-cancer treatments prescribed, and the Portuguese annual inflation (available at PORDATA) was considered for adjusted costs $(€)^{9,10}$ The prices shown are for the listed drugs only; variable direct costs such as premedication, blood tests and indirect costs including those associated with supportive care and toxicities management, hospitalizations and clinical visits were excluded from this analysis.

As shown in Table 1, the total treatment-related cost

\footnotetext{
1. Taussig Cancer Institute Cleveland Clinic. Cleveland. United States of America.

2. Instituto CUF de Oncologia (I.C.O.). Lisboa. Portugal.

3. Hospital Beatriz Ângelo. Loures. Portugal.

4. Centro Hospitalar de Lisboa Central. Lisboa. Portugal.

$\triangle$ Autor correspondente: Pedro Coelho Barata. pedrobaratamd@gmail.com

Recebido: 25 de novembro de 2017 - Aceite: 09 de maio de 2018 | Copyright @ Ordem dos Médicos 2018
} 
Table 1 - Drug cost of treatment for a patient with mRCC in the years 2011, 2014 and 2018

\begin{tabular}{|llll}
\hline & Case A (2011) & Case B (2014) & Case C (2018) \\
\hline First-line & Sunitinib & Sunitinib & Ipilimumab/ Nivolumab \\
\hline Treatment duration, months & 11.0 & 11.0 & 11.6 \\
\hline Cost (drug/month of treatment), $€$ & 4533.2 & 3689.2 & 7309.0 \\
\hline Total Cost ${ }^{1}$ (line of therapy), $€$ & 32865.7 & 26746.7 & 84784.0 \\
\hline Second-line & Everolimus & Axitinib & Cabozantinib \\
\hline Treatment duration, months & 3.8 & 8.3 & 7.4 \\
\hline Cost (drug/month of treatment), $€$ & 4747.2 & 2983.2 & 5777.0 \\
\hline Total Cost ${ }^{1}$ (line of therapy), $€$ & 18039.36 & 24760.6 & 42749.1 \\
\hline Third-line & Sorafenib & Everolimus & Axitinib \\
\hline Treatment duration, months & 3.5 & 3.7 & 5.9 \\
\hline Cost (drug/month of treatment), $€$ & 3650.4 & 2983.5 & 2868.4 \\
\hline Total Cost (line of therapy), $€$ & 12776.4 & 11039.0 & 16923.7 \\
\hline Total Cost ${ }^{1}, €$ & 63681.46 & 62546.3 & 144456.8 \\
\hline
\end{tabular}

${ }^{1}$ Cost of treatment $(€)$ adjusted to annual inflation in Portugal ${ }^{10}$

per patient with $\mathrm{mRCC}$ in 2011 was estimated to be $63,681.46 €$, compared with $62546.3 €$ in 2014 and 144 $456.8 €$ in 2018 , respectively. Thus, the cost of drug treatment for $\mathrm{mRCC}$ has increased $127 \%$, after adjusting for inflation, over the past seven years. When the treatment is restricted to two sequential lines of treatment, the total drug cost is estimated to have increased $151 \%$ between 2011 and 2018.

The drug cost of anti-cancer therapies reflects the cost of research and development (of both successful as well as failed drugs) and cost of production and distribution of drugs. Whether the rapidly rising cost of drugs to the health care system (as shown here) translates into meaningful clinical benefit, should be measured in the conceptual frameworks developed by leading medical professional societies such as the European Society for Medical Oncology (ESMO) or the American Society of Clinical Oncology (ASCO). ${ }^{11}$

The combination of ipilimumab and nivolumab represents the most expensive treatment option for $\mathrm{mRCC}$ to date, but it is also the first regimen to demonstrate an OS benefit in the front-line setting against standard therapy. Several other phase III studies testing multiple combinations of immune checkpoint inhibitors with targeted therapies are ongoing, with preliminary promising results. As a consequence, the treatment of $\mathrm{mRCC}$ will likely continue to change to include multiple combinations of active and, probably, expensive drugs. Furthermore, as additional successful therapies become available, more patients will benefit from further lines of treatment, challenging finances even further.

This financial exercise in $\mathrm{mRCC}$ illustrates a societal challenge in Oncology and, possibly, in other areas of Medicine. Increasing population life expectancy, prolongation of disease duration with greater number of cancers becoming chronic diseases and more successful treatments available challenge the ability of society to deliver affordable, high-quality cancer care to all its citizens. Oncologists and other clinicians have been leading voices on the issues of affordability of cancer drugs. Concrete solutions have been offered, including (but not limited to) defining value of cancer treatment regimens and testing different value-based pricing strategies, encouraging the development of generics and biosimilars, transparency in drug costs and negotiation of volume discounts with manufacturers. While we should be celebrating the promising results of our collective work in advancing the treatment of $\mathrm{mRCC}$, we must continue to work together on next steps to ensure access, affordability and innovation to our cancer patients in the near future.

\section{ACKNOWLEDGEMENTS}

The authors would like to thank António Melo Gouveia, Rute Varela and Mónica Canha for their valuable help with the economic evaluation exercise presented herein.

\section{REFERENCES}

1. Ferlay J, Steliarova-Foucher E, Lortet-Tieulent J, Rosso S, Coebergh JW, Comber $\mathrm{H}$, et al. Cancer incidence and mortality patterns in Europe: estimates for 40 countries in 2012. Eur J Cancer. 2013;49:1374-403.

2. Siegel RL, Miller KD, Jemal A. Cancer statistics, 2017. CA Cancer J Clin. 2017;67:7-30.

3. Barata PC, Rini BI. Treatment of renal cell carcinoma: current status and future directions. CA Cancer J Clin. 2017;67:507-24.

4. Motzer RJ, Tannir NM, McDermott DF, Frontera OA, Melichar B, Choueiri TK, et al. Nivolumab plus Ipilimumab versus sunitinib in advanced renalcell carcinoma. N Engl J Med. 2018;378:1277-90.
5. Wells JC, Stukalin I, Norton C, Srinivas S, Lee JL, Donskov F, et al. Third-line targeted therapy in metastatic renal cell carcinoma: results from the International Metastatic Renal Cell Carcinoma Database Consortium. Eur Urol. 2017;71:204-9.

6. Organization for Economic Co-operation and Development. Health at a Glance 2017. Paris: OECD Publishing; 2017.

7. van Harten WH, Wind A, de Paoli P, Saghatchian M, Oberst S. Actual costs of cancer drugs in 15 European countries. Lancet Oncol. 2016;17:18-20.

8. European Medicines Agency. Therapeutic areas: cancer. 2017. 
[accessed 2017 Nov 30]. Available from: http://www.ema.europa.eu/ ema/index.jsp?curl=pages/special_topics/landing/cancer_disease_ area.jsp\&mid=WC0b01ac058034ed06.

9. Infarmed. Autoridade Nacional do Medicamento e Produtos de Saúde. 2017. [accessed 2017 Nov 30]. Available from: http://www.infarmed.pt/ web/infarmed/legislacao/legislacao-farmaceutica-compilada/titulo-ivcomparticipacoes.

10. Fundação Manuel Dos Santos. Macroeconomia: preços e deflatores.
2017 [accessed 2017 Nov 30]. Available from: http://www.pordata.pt/ Portugal/Taxa+de+Infla \%C3\%A7\%C3\%A3o+(Taxa+de+Varia\%C3\%A7 $\% \mathrm{C} 3 \% \mathrm{~A} 30+$ do+\%C3\%8Dndice+de+Pre $\% \mathrm{C} 3 \% \mathrm{~A} 7 \mathrm{os}+$ no+Consumidor) +total+e+por+consumo+individual+por+objectivo-2315-181662.

11. Becker DJ, Lin D, Lee S, Levy BP, Makarov DV, Gold HT, et al. Exploration of the ASCO and ESMO Value Frameworks for Antineoplastic Drugs. J Oncol Pract. 2017;13:e653-65. 